\title{
Öğretmenlerin Yansıtıcı Düşünme Becerilerinin Çeşitli Değişkenlere Göre İncelenmesi
}

\author{
DOI: 10.26466/opus.550187 \\ * \\ Yalçın Dilekli - Senol Orakc1 ${ }^{* *}$ \\ * Dr, Aksaray Üniversitesi, Eğitim Fakültesi, Merkez /Aksaray/ Türkiye \\ E-Posta: dilekliyalcin@gmail.com \\ ORCID: 0000-0003-0264-0231 \\ ** Dr, Aksaray Üniversitesi, Eğitim Fakültesi, Merkez /Aksaray/ Türkiye \\ E-Posta: senolorak@gmail.com \\ ORCID: $\quad$ 0000-0003-1534-1310
}

\section{Öz}

Yansıtıcı düşünme, önceki deneyimleri hatırlama, onları düşünme ve tartışma, uygun düşünceler üretme ve değerlendirme süreci olarak tanımlanabilir. Bu çalışmada, öğretmenlerin yansıtıcı düşünme düzeylerini belirlemek, öğretmenlerin branş, cinsiyet, öğrenim düzeyi, okul türü ve mesleki kıdemlerine göre bu düzeylerin anlaml bir farklılık gösterip göstermediğini incelemek ve öğretmelerin yansitıcı düşünme becerileri puanlar üzerinde branş, cinsiyet, öğrenim düzeyi, görev yapılan okul türü ve mesleki kıdem değişkenlerinden hangisinin daha çok etkili olduğu tespit etmek amaçlanmıştır. Bu araştırmanın örneklemini, Türkiye'nin farklı illerinde farklı kademelerde farklı branşlarda görev yapan toplam 630 öğretmen oluşturmaktadır. Bu araştırma tarama modeli kullanilarak yürütülen betimsel bir araştırma çalışmasıdır. Verilerin toplanması için araştırmacılar tarafından kişisel bilgi formu oluşturulmuştur. Ayrıca araştırmada "Yansıtıcı Düşünme Ĕ̆̈ilim Ölçeği" (YANDE) kullanılmıştır. Veri analizinde çalışmanın amacı doğrultusunda "bağımsız grup $t$ testi" "varyans analizi" ve post-hoc tekniklerden biri olarak "Tukey testi" kullanılmıştır. Araştırma sonucunda öğretmenlerin yansıtıcı düşünme düzeyleri açısından branşlarına, cinsiyetlerine, öğrenim düzeylerine ve görev yaptıkları okul türüne göre anlaml farklilık olduğu tespit edilmiştir. Araştırma sonuçları, yansıtıcı düşünme üzerine yapılan benzer araştırma sonuçlarıyla ilişkilendirilerek tartışılmıştır.

Anahtar Kelimeler: Öğretmenler, Yansıtıcı düşünme, Yansıtıcı öğretmen, Karar ă̆acı. 


\title{
Analyzing Teachers' Reflective Thinking in terms of Some Variables
}

\begin{abstract}
Reflective thinking can be defined as recalling previous experiences, thinking and discussing them, producing suitable ideas, and evaluating them. In this study, it is aimed to determine reflective thinking levels of teachers and to examine whether there is a significant difference between teachers' branches, gender, education level, type of school and professional seniority and determine which of teachers' branches, gender, education level, type of school and professional seniority were more effective on the reflective thinking skills scores of the teachers. The sample of this study constitutes a total of 630 teachers working in different branches at different levels in different provinces of Turkey. This study is a descriptive research study conducted using the screening model. A personal information form was created by the researchers to collect the data. In addition, "Reflective Thinking Tendency Scale (YANDE)" was used in the study. In the analysis of the data, "independent group $t$ test", one-way variance analysis (ANOVA), "Tukey test", one of the post-hoc techniques were used for the purpose of the study. At the end of the study, it was determined that there was a significant difference in terms of the reflective thinking levels of the teachers according to their branches, gender, level of education and the type of school they served. The results of the study were discussed with the results of similar studies on teachers' reflective thinking.
\end{abstract}

Keywords: Teachers, Reflective thinking, Reflective teacher, Decision tree. 


\section{Giriş}

Yansıtıcı düşünme, bilinçli olarak öğrenilen ve geliştirilen bilişsel bir özelliktir. Bu nedenle, okul ortamında bu tür bir düşünceye sahip olmak önemlidir (Wilson ve Jan, 1993). Eğitimde yapılandırmacılığa önem veren bir sorgulama yaklaşımı olan yansıtıcı düşünme, bireyin yaşadıklarını yeniden inşa etmesini içermektedir (Mahnaz, 1997). Aynı zamanda yansıtıcı düşünme, bir durumu veya sorunu anlamak ve buna ilişkin daha iyi bir çözüm bulmayı içeren düşünme çeşitidir (Kızılkaya ve Aşkar, 2009)

Yansitıcı düşünme, Dewey'(1933) in öncü olduğu pragmatik felsefenin odak noktalarından biridir. Dewey (1933) için, yansıtıcı düşünme, "amaçlanan sonuçlara ulaşmayı destekleyen her türlü düşünce veya bilgi yap1sinı etkili, tutarlı ve dikkatli düşünmektir" (Dewey, 1933, s.6). Mevcut deneyimler, yansıtıcı düşünme sürecinde yeniden düzenlenir veya inşa edilir. Böylece, anlamlı deneyimler sonraki deneyimlerin gerçekleşmesini etkiler. Bu süreç ise durumun tanımlanması ile başlar, durum hakkında neler yapılabileceği sıralanarak, uygulama için gelecek planları yapılarak ve neler yapıldığı açıklanarak döngüsel olarak devam eder (Dewey 1933; Tripp, 2003). Willard-Holt ve Bottomley (2000), yansitmayı gerçekleştiren bireylerin yansıtmayı öğrenmeyi ve öğrendikten sonra da devam etmeyi sürdürdüğ̈̈nü belirterek söz konusu bu döngüye dikkat çekmektedir.

Yansitıcı düşünme, önceki deneyimleri hatırlama, onları düşünme ve tartışma ve belli bir hedefe dayanarak yeniden değerlendirme sürecidir (Atay, 2003). Yansitıcı düşünme sürecinin temeli, sorunu ve arayış çözümlerini belirlemektir. Lee (2005) ve Loughran (2002) yalnızca çözüme odaklanmakla kalmamakta, aynı zamanda süreci ve ilerlemeyi de değerlendirmektedir. Yansitıcı düşünme, uygun düşüncelerin üretildiği, seçildiği ve uygun olmayanların ortaya çıktığı bir süreçtir (Gelter, 2003).

Eğitim hedeflerini gerçekleştirmede, sorunlara çözüm aramada ve mevcut durumlarını değerlendirmede anahtar rolü olduğu için yansıtıcı düşüncenin öğretmenler için gerekli olduğu söylenebilir. Öğretmenlerin konuyla ilgili fikirlerini, tutumlarını ve becerilerini ifade etme süreci yansitma olarak tanımlanmaktadır (Semerci, 2007; Dilekli, 2018).

Yansıtıcı düşünme, öğretmenler açısından onların mesleki uygulamalarını yorumlamak ve geliştirmek için düzenli olarak yapmaları gereken bir öz-inceleme ve öz-değerlendirme süreci olarak ifade edilmektedir 
(Husu, Toom ve Patrikainen, 2006). Danielson (1996), ise yansıtıcı düşünmeyi genellikle daha geniş bir amaç için bir tecrübenin hatırlandığı ve değerlendirildiği bir faaliyet veya süreç olarak ifade etmiştir. Yansıtıcı düşünme, geçmiş deneyime bir cevaptır ve bilinçli hatırlama ve deneyimin değerlendirme ve karar vermeye yönelik olarak bir temel olarak incelenmesini ve eylem için ise bir kaynak olarak incelenmeyi içermektedir.

Yansıtıcı düşünme süreci, öğretmenlerin sistematik olarak, sürekli inceleme ve çözüm geliştirmek için araştırma yapmalarını gerektirir. Yansıtıcı düşünen öğretmenler kendilerine sorular sorar, kendi performanslarını analiz eder ve hedeflerini yeniden düzenleyerek performansın nasıl artırılacağını belirlemektedirler (Alp ve Taşkın, 2008; Ayers 2001; Loughran 2002).

Öğretmenler için öğrenme süreci uygulamalara yönelik olmalı, bu süreç uygulamalardan elde edilen deneyimlere dayanmalı ve bu nedenle, deneyim öğrenmesinin ardından hemen yansıtıcı düşünme faaliyetine geçilmelidir (Harrison, Dymoke ve Pell 2006). Donald ve diğ. (2006), öğretim, öğretmenlerin yaptıkları hakkında düşünmelerini gerektiren karmaşık bir faaliyettir. İyi öğretmenler, öğretimleri üzerinde düşünerek daha da etkili olabilirler. Bu görüşe göre, öğretmenin yansıtıcı düşünmesi kişinin öğretmesine yönelik eleştirel yaklaşımları teşvik eder ve sonuç olarak daha iyi uygulamaları beraberinde getirmektedir (Oser, Dick ve Paltry, 1992; Artzt ve Armor-Thomas, 2001; Mayes, 2001; Swain, 1998).Öğretmenler uygulamaya yönelik yapılan hatalarının farkında olmazlarsa, kendi alanlarında ya da öğretim yöntemleri konusunda ne kadar deneyimli olurlarsa olsunlar, bu hataların tekrarlanmasını önlemek için gereken önlemlerin farkında olmayacaktır. Bu açıdan bakıldığında, yansıtıcı düşünme sayesinde öğretmenler, ne yaptıklarını sorgulayabilir, bunları tekrar yapılandırabilir, bu değişiklikleri uygulayabilir ve böylece kendilerini geliştirebilirler (Bölükbaş, 2004). Bu nedenle, yansitıcı düşünme, öğretmenlerin teori ve pratik arasında ilişki kurmasına yardımcı olan ve mesleki gelişimine katkıda bulunan bir beceridir (Güney, 2008).

Bu çalışmada, öğretmenlerin yansıtıcı düşünme düzeylerini belirlemek amaçlanmaktadır. Bu amacı gerçekleştirmek için aşağıdaki sorulara yanıtlar aranmaktadır.

1. Öğretmenlerinin yansıtıcı düşünme düzeyleri nasıldır? 
2. Öğretmenlerinin branşlarına göre yansıtıcı düşünme düzeyleri arasında anlamlı bir fark var midır?

3. Öğretmenlerinin cinsiyetlerine göre yansıtıcı düşünme düzeyleri arasında anlamlı bir fark var midır?

4. Öğretmenlerinin öğrenim düzeylerine göre yansıtıcı düşünme düzeyleri arasında anlamlı bir fark var mıdır?

5. Öğretmenlerin görev yaptıkları okul türüne göre yansıtıcı düşünme düzeyleri arasında anlamlı bir fark var mıdır?

6. Öğretmenlerinin mesleki kıdemlerine göre yansıtıcı düşünme düzeyleri arasında anlamlı bir fark var midır?

7. Öğretmeleri yansitıcı düşünme becerileri puanları üzerinde branş, cinsiyet, öğrenim düzeyi, görev yapılan okul türü ve mesleki k1dem değişkenlerinden hangisi daha çok etkilidir?

\section{Yöntem}

$\mathrm{Bu}$ araştırma tarama modeli kullanılarak yürütülen betimsel bir araştırma çalışmasıdır. Tarama modeli, mevcut durumu geçmişte veya şu anda olduğu gibi tanımlamayı amaçlayan bir modeldir (Karasar, 2011).

\section{Çalışma Grubu}

Bu araştırmanın çalışma grubu belirlenirken amaçlı örneklem yöntemi benimsenmiş olup, araştırmanın çalışma grubunu Türkiye'de farklı illerde görev yapan 353'ü erkek, 277'si kadın toplam 630 öğretmen oluşturmaktadir.

\section{Veri Toplama Aracı}

Verilerin toplanması için araştırmacılar tarafından kişisel bilgi formu geliştirilmiştir. Ayrıca araştırmada Semerci (2007) tarafından geliştirilen "Yansitıcı Düşünme Eğilim Ölçeği" (YANDE) kullanılmıştır. Yansitıcı Düşünme Eğilimi Ölçeği, 5'li Likert tipi bir ölçek olarak tasarlanmıştır ve toplam 35 maddeden (20 pozitif ve 15 negatif) oluşmaktadır. Ölçeğin yedi alt boyutu vardır: "sürekli ve amaçlı düşünme"; "açık fikirlilik"; "sorgu- 
layıcı ve etkili öğretim"; "öğretim sorumluluğu ve bilimsellik"; "araştırmacı"; "öngörülü ve içten olma"; ve "mesleğe bakış"tır. Cronbach'ın alfa katsayısı genel ölçek için “ 0,908 " dir. Alt boyutlar için sırasıyla 0,794; 0,712; $0.747 ; 0.776 ; 0.742 ; 0.668$; ve 0.357 'dir. Bu ölçekte, Cronbach'ın alfa katsayısı ölçeğin tümü için $0,878^{\prime}$ dir.

\section{Verilerin Analizi}

Verilerin analizinde SPSS paket programı kullanılmıştır. Veriler analiz edilirken çalışmanın amacı doğrultusunda "bağımsız grup t testi" "varyans analizi" ve post-hoc tekniklerden biri olan "Tukey testi" kullanılmıştır.

\section{Bulgular}

Öğretmenlerin yansıtıcı düşünme eğilimi ölçek alt puanlarına ait ortalama ve standart sapma değerleri Tablo 1'de sunulmuştur.

Tablo 1.Alt Ölçeklerinin n, X ve SS Değerleri

\begin{tabular}{llll}
\hline Alt Ölçekler & $\mathrm{N}$ & $\overline{\mathrm{X}}$ & $\mathrm{ss}$ \\
\hline Sürekli ve amaçlı düşünme & 630 & 28,94 & 4.50 \\
Açı fikirlilik & 630 & 29,32 & 4.60 \\
Sorgulayıcı ve etkili öğretim & 630 & 21,76 & 3.85 \\
Öğretim sorumluluğu ve bilimsellik & 630 & 21,11 & 3.52 \\
Araştırmacı & 630 & 25,27 & 4.31 \\
Öngörülü ve içten olma & 630 & 16,72 & 3.34 \\
Mesleğe bakış & 630 & 8,3 & 1.69 \\
\hline
\end{tabular}

Öğretmenlerin yansıtıcı düşünme eğilimlerini ifade eden puanların ortalamaları 8.30 ile 28.94 arasında değişmektedir. En yüksek ortalama (Ort. 29,32; SS 4.60) aç1k fikirlilik alt boyutunda yer alırken, en düşük ortalama (Ort. 8.30; SS 1,69) mesleğe bakış alt boyutunda yer almaktadır.

Öğretmenlerin yansıtıcı düşünme eğilimlerinin branş değişkenine göre değişip değişmediğine dair yapılan tek yönlü varyans analizi sonuçları Tablo 2'de verilmiştir. 
Tablo 2. Yansıtıcı düşünme alt ölçek puanlarının branş değişkenine Göre Tek Yönlü Varyans Analizi (ANOVA) sonuçlart

\begin{tabular}{|c|c|c|c|c|c|c|c|c|}
\hline Alt Ölçekler & Branş & $\mathbf{N}$ & $\bar{X}$ & ss. & & K. O. & $F$ & $\mathrm{p}$ \\
\hline S. ve A. & Fen_Mat & 151 & 28,41 & 4,6 & G. A & 36.983 & 1.809 & 1.25 \\
\hline \multirow[t]{5}{*}{ Düşünme } & Türkçe. Sosyal & 199 & 29,92 & 4,57 & & & & \\
\hline & Meslek & 63 & 28,31 & 5,12 & G.İ. & 20.441 & & \\
\hline & Sinif & 106 & 29,7 & 4,13 & & & & \\
\hline & İngilizce & 111 & 29,35 & 4,27 & & & & \\
\hline & Toplam & 630 & 28,94 & 5,33 & & & & \\
\hline Açık & Fen_Mat & 151 & 25,95 & 4,47 & G. A & 62.802 & 3.005 & $.018^{*}$ \\
\hline \multirow{5}{*}{ Fikirlilik } & Türkçe. Sosyal & 199 & 26,16 & 4,68 & & & & \\
\hline & Meslek & 63 & 25,14 & 5,53 & G.İ. & 20.902 & & \\
\hline & Sinif & 106 & 27,33 & 3,79 & & & & \\
\hline & İngilizce & 111 & 26,82 & 4,57 & & & & \\
\hline & Toplam & 630 & 26,32 & 4,6 & & & & \\
\hline S. ve E. & Fen_Mat & 151 & 21,41 & 3,64 & G. A. & 29.54 & 2.006 & .092 \\
\hline \multirow[t]{5}{*}{ Öğretim } & Türkçe. Sosyal & 199 & 21,73 & 3,87 & & & & \\
\hline & Meslek & 63 & 20,98 & 4,34 & & & & \\
\hline & Sinif & 106 & 22,45 & 3,5 & G.İ. & 14.734 & & \\
\hline & İngilizce & 111 & 22,07 & 4,02 & & & & \\
\hline & Toplam & 630 & 21,76 & 4,6 & & & & \\
\hline Ö.S. ve & Fen_Mat & 151 & 20,74 & 3,2 & G.A. & 1.246 & 1.636 & .163 \\
\hline \multirow[t]{5}{*}{ Bilimsellik } & Türkçe. Sosyal & 199 & 20,95 & 3,66 & & & & \\
\hline & Meslek & 63 & 20,95 & 4,14 & & & & \\
\hline & Sinif & 106 & 21,75 & 3,38 & & & & \\
\hline & İngilizce & 111 & 21,41 & 3,41 & G.İ. & .557 & & \\
\hline & Toplam & 630 & 21,11 & 3,52 & & & & \\
\hline \multirow[t]{6}{*}{ Araştırmacı } & Fen_Mat & 151 & 25,03 & 4,01 & G.A. & 1.329 & 1.073 & .690 \\
\hline & Türkçe. Sosyal & 199 & 25,07 & 4,34 & & & & \\
\hline & Meslek & 63 & 25,44 & 4,78 & G.İ. & .615 & & \\
\hline & Sinif & 106 & 25,68 & 4,27 & & & & \\
\hline & İngilizce & 111 & 25,48 & 4,48 & & & & \\
\hline & Toplam & 630 & 25,27 & 4,31 & & & & \\
\hline Ö. ve & Fen_Mat & 151 & 16,5 & 3,14 & G.A. & 1.329 & 1.169 & .369 \\
\hline \multirow[t]{5}{*}{ İ. Olma } & Türkçe. Sosyal & 199 & 16,55 & 3,38 & & & & \\
\hline & Meslek & 63 & 16,84 & 3,83 & G.İ. & .615 & & \\
\hline & Sinif & 106 & 17,29 & 2,91 & & & & \\
\hline & İngilizce & 111 & 16,72 & 3,65 & & & & \\
\hline & Toplam & 630 & 16,72 & 3,34 & & & & \\
\hline Mesleğe & Fen_Mat & 151 & 8,33 & 1,68 & G. A. & 1.329 & 1.196 & .311 \\
\hline \multirow[t]{5}{*}{ Bakış } & Türkçe. Sosyal & 199 & 8,18 & 1,69 & & & & \\
\hline & Meslek & 63 & 8,07 & 1,7 & G.İ. & .615 & & \\
\hline & Sinif & 106 & 8,56 & 1,62 & & & & \\
\hline & İngilizce & 111 & 8,34 & 1,78 & & & & \\
\hline & Toplam & 630 & 8,3 & 1,69 & & & & \\
\hline
\end{tabular}

${ }^{*} p<.05 ; d f=4$

Analiz sonucunda öğretmenlerin yansıtıcı düşünme eğilimlerinde sadece açık fikirlilik alt boyutunda anlamlı bir farklılık belirlenmiştir ( $\mathrm{F}=3.005$, 
p<.05). Farkın kaynağını belirlemek için yapılan Tukey analizinde sınıf öğretmenleri (Ort. 27.33; SS: 3,79) ve mesleki teknik eğitim branşında (Ort. 25,14; SS: 5,53) görev yapan öğretmenler arasında sınıf öğretmenleri lehine anlamlı bir farklılık bulunmuştur

Tablo 3. Yansıtıcı düşünme alt ölçek puanlarının cinsiyet değişkenine göre t-Testi sonuçları

\begin{tabular}{lllllll}
\hline Ölçek & Cinsiyet & $\mathbf{N}$ & $\overline{\mathbf{X}}$ & ss. & $\mathbf{t}$ & $\mathbf{p}$ \\
\hline S. ve A. Düşünme & Erkek & 353 & 28,63 & 4,76 & 1.971 & $.046^{*}$ \\
& Kadın & 277 & 29,35 & 4,19 & & \\
\hline Açık fikirlilik & Erkek & 353 & 25,93 & 4,92 & 2.407 & $.016^{*}$ \\
& Kadın & 277 & 26,82 & 4,10 & & \\
\hline S.ve E. Öğretim & Erkek & 353 & 21,50 & 4,15 & 1.900 & .052 \\
& Kadın & 277 & 22,09 & 3,39 & & \\
\hline Ö.S. ve Bilimsellik & Erkek & 353 & 20,97 & 3,65 & 1.161 & .246 \\
& Kadın & 277 & 21,30 & 3,36 & & \\
\hline Araştırmacı & Erkek & 353 & 25,05 & 4,51 & 1.441 & .150 \\
& Kadın & 277 & 25,55 & 4,04 & & \\
\hline Ö. ve İ. Olma & Erkek & 353 & 16,68 & 3,33 & .338 & .736 \\
& Kadın & 277 & 16,77 & 3,35 & & \\
\hline Mesleğe Bakış & Erkek & 353 & 8,17 & 1,74 & 2.106 & $.034^{*}$ \\
& Kadın & 277 & 8,46 & 1,62 & & \\
\hline
\end{tabular}

${ }^{*} \mathrm{p}<.05 ; \mathrm{df}=4$

Öğretmenlerin yansıtıcı düşünme eğilimlerinin cinsiyet açısından farklılık gösterip göstermediğini belirlemek için t Testi ile analiz yapılmıştır. Analiz Sonuçları Tablo 3'de sunulmuştur.

Öğretmenlerin yansıtıcı düşünme eğilimlerinin cinsiyet açısından farklılık gösterip göstermediğini belirlemek için $t$ Testi sonuçlarına göre, Sürekli ve amaçlı düşünme alt boyutunda kadınlar lehine anlamlı bir farklılık bulunmuştur. Kadınların ortalaması 29,35 ( $\mathrm{t}=1.971, \mathrm{p}<.05)$ erkeklerin ortalaması 26,82 ( $\mathrm{t}=1.971, \mathrm{p}<.05)^{\prime}$ dır. Açık fikirlilik boyutunda kadınların ortalama puanları Ort. 25,93(t=2.407, $\mathrm{p}<.05)$ daha yüksektir. Anlamlı farklıl1ğın bulunduğu üçüncü ve son alt boyut ise mesleğe bakış boyutudur. Yine aynı şekilde kadınların mesleğe bakış ortalamaları Ort. $8.46(\mathrm{t}=2.106$, $\mathrm{p}<.05$ ) iken erkek öğretmelerin ortalamaları 8,17( $\mathrm{t}=2.106, \mathrm{p}<.05)^{\prime}$ dir.

Öğretmenlerin yansitıcı düşünme eğilimlerinin öğrenim düzeyi değişkenine göre değişiklik gösterip göstermediğine yönelik yapılan Tek yönlü varyans analizi sonuçları Tablo 4'de sunulmuştur. 
Tablo 4. Yansıtıcı düşünme alt ölçek puanlarının öğrenim düzeyi değişkenine göre Tek yönlï varyans analizi (ANOVA) sonuçları

\begin{tabular}{|c|c|c|c|c|c|c|c|c|}
\hline Alt Ölçekler & & $\mathbf{N}$ & $\overline{\mathrm{X}}$ & ss. & & O. & $\mathbf{F}$ & p \\
\hline S. A. & Ö.Lisans & 71 & 30.45 & 4.12 & G. A. & 94,36 & 4,644 & $.010^{*}$ \\
\hline \multirow[t]{3}{*}{ Düşünme } & Lisans & 407 & 28.62 & 4.38 & G.İ. & 20,31 & & \\
\hline & L. Üstü & 152 & 29.15 & 4.98 & & & & \\
\hline & Toplam & 630 & 28.94 & 4.53 & & & & \\
\hline Açık & Ö.Lisans & 71 & 27.23 & 4.8 & G. A. & 39,86 & 1.889 & .152 \\
\hline \multirow[t]{3}{*}{ Fikirlilik } & Lisans & 407 & 26.0 & 4.3 & G.İ. & 21,1 & & \\
\hline & L.Üstü & 152 & 25.0 & 5.6 & & & & \\
\hline & Toplam & 630 & 26.32 & 4.60 & & & & \\
\hline \multirow{4}{*}{$\begin{array}{l}\text { S. E. } \\
\text { Öğretim }\end{array}$} & Ö.Lisans & 71 & 21.71 & 4.23 & G. A. & 1,06 & .068 & .935 \\
\hline & Lisans & 407 & 21.73 & 3.64 & G.İ. & 14,86 & & \\
\hline & L.Üstü & 152 & 21.86 & 4.20 & & & & \\
\hline & Toplam & 630 & 21.76 & 3.85 & & & & \\
\hline \multirow{4}{*}{$\begin{array}{l}\text { Ö.S.ve } \\
\text { Bilimsellik }\end{array}$} & Ö.Lisans & 71 & 20.64 & 3.46 & G. A. & 17,95 & 1.445 & .237 \\
\hline & Lisans & 407 & 21.06 & 3.51 & G.İ. & 12,42 & & \\
\hline & L.Üstü & 152 & 21.47 & 3.58 & & & & \\
\hline & Toplam & 630 & 21.11 & 3.52 & & & & \\
\hline \multirow[t]{4}{*}{ Araştırmacı } & Ö.Lisans & 71 & 25.91 & 3.83 & G. A. & 33,36 & 1.792 & .167 \\
\hline & Lisans & 407 & 25.04 & 4.31 & G.İ. & 14,12 & & \\
\hline & L. Üstü & 152 & 25.59 & 4.51 & & & & \\
\hline & Toplam & 630 & 25.27 & 4.31 & & & & \\
\hline \multirow[t]{4}{*}{ Ö. İ. Olma } & Ö.Lisans & 71 & 16.33 & 3.76 & G. A. & 23,51 & 2.114 & \\
\hline & Lisans & 407 & 16.62 & 3.32 & G.İ. & 11,12 & & \\
\hline & L.Üstü & 152 & 17.18 & 3.13 & & & & \\
\hline & Toplam & 630 & 16.72 & 3.34 & & & & \\
\hline Mesleğe & Ö.Lisans & 71 & 8.50 & 1.56 & G. A. & 1,84 & .638 & .529 \\
\hline \multirow[t]{3}{*}{ Bakış } & Lisans & 407 & 8.28 & 1.69 & G.İ. & 2,89 & & \\
\hline & L.Üstü & 152 & 8.23 & 1.77 & & & & \\
\hline & Toplam & 630 & 8.30 & 1.69 & & & & \\
\hline
\end{tabular}

\footnotetext{
${ }^{*} \mathrm{p}<.05 ; \mathrm{df}=2$
}

Öğretmenlerin yansitıcı düşünme eğilimlerinin öğrenim durumu değişkeni açısından farklılık gösterip göstermediğini belirlemek için yapılan tek yönlü varyans analizi (ANOVA) sonuçlarına göre, sürekli ve amaçlı düşünme alt boyutunda anlamlı bir farklılık bulunmuştur $(\mathrm{F}=4,644 \mathrm{p}<.05)$. Farklılığın kaynağını belirlemek amacıyla yapılan Tukey analizinde ön lisans mezunları ile lisans mezunları arasında ön lisans mezunları lehine anlamlı bir fark bulunmuştur (Ort. 30,35; $\mathrm{p}<.05$ ).

Öğretmenlerin yansıtıcı düşünme eğilimlerinin görev yapılan okul türü değişkenine göre değişiklik gösterip göstermediğine yönelik yapılan Tek yönlü varyans analizi sonuçları Tablo 5'te sunulmuştur. 
Tablo 5. Yansıtıcı düşünme alt ölçek puanlarının okul türü değişkenine göre Tek yönlü varyans analizi (ANOVA) sonuçları

\begin{tabular}{|c|c|c|c|c|c|c|c|c|}
\hline Alt Ölçekler & & $\mathbf{N}$ & $\overline{\mathrm{X}}$ & ss & & K.O. & $\mathbf{F}$ & $\mathrm{p}$ \\
\hline S. A. & Anadolu L. & 128 & 29.27 & 4.37 & G. A. & 46,32 & 2,28 & .035 \\
\hline \multirow[t]{7}{*}{ Düşünme } & Sos./Fen L. & 32 & 27.81 & 4.82 & G. İ. & 20,3 & & \\
\hline & İmam H.L. & 37 & 28.27 & 3.94 & & & & \\
\hline & Meslek L. & 30 & 27.20 & 5.84 & & & & \\
\hline & İlkokul & 108 & 29.66 & 4.27 & & & & \\
\hline & Ortaokul & 226 & 28.68 & 4.37 & & & & \\
\hline & B. Sanat M. & 69 & 29.73 & 4.96 & & & & \\
\hline & Toplam & 630 & 28.94 & 4.53 & & & & \\
\hline \multirow[t]{8}{*}{ Açık fikirlilik } & Anadolu L. & 128 & 26.71 & 4.47 & G. A. & 49,25 & 2357 & .029 \\
\hline & Sos./Fen L. & 32 & 26.31 & 3.07 & & & & \\
\hline & İmam H.L. & 37 & 24.86 & 5.28 & G. İ. & 20,89 & & \\
\hline & Meslek L. & 30 & 24.56 & 5.94 & & & & \\
\hline & İlkokul & 108 & 27.27 & 3.61 & & & & \\
\hline & Ortaokul & 226 & 26.15 & 4.47 & & & & \\
\hline & B. Sanat M. & 69 & 26.23 & 5.76 & & & & \\
\hline & Toplam & 630 & 26.32 & 4.60 & & & & \\
\hline \multirow[t]{8}{*}{ S. E. Öğretim } & Anadolu L. & 128 & 21.45 & 4.00 & G. A. & 19,61 & 1327 & .243 \\
\hline & Sos./Fen L. & 32 & 21.87 & 3.21 & & & & \\
\hline & İmam H.L. & 37 & 21.54 & 3.50 & G. İ. & 14,77 & & \\
\hline & Meslek L. & 30 & 20.63 & 4.67 & & & & \\
\hline & İlkokul & 108 & 22.53 & 3.55 & & & & \\
\hline & Ortaokul & 226 & 21.73 & 3.57 & & & & \\
\hline & B. Sanat M. & 69 & 21.76 & 4.75 & & & & \\
\hline & Toplam & 630 & 21.76 & 3.85 & & & & \\
\hline Ö.S.ve & Anadolu L. & 128 & 20.26 & 3.52 & G. A. & 29,28 & 2384 & .028 \\
\hline \multirow[t]{7}{*}{ Bilimsellik } & Sos./Fen L. & 32 & 20.78 & 3.94 & & & & \\
\hline & İmam H.L. & 37 & 21.56 & 3.22 & G. İ. & 12,28 & & \\
\hline & Meslek L. & 30 & 20.20 & 4.52 & & & & \\
\hline & İlkokul & 108 & 21.53 & 3.37 & & & & \\
\hline & Ortaokul & 226 & 21.36 & 3.25 & & & & \\
\hline & B. Sanat M. & 69 & 21.56 & 3.86 & & & & \\
\hline & Toplam & 630 & 21.11 & 3.52 & & & & \\
\hline \multirow[t]{8}{*}{ Araştırmacı } & Anadolu L. & 128 & 24.32 & 4.27 & G. A. & 45,1 & 2,451 & .024 \\
\hline & Sos./Fen L. & 32 & 25.09 & 4.40 & & & & \\
\hline & İmam H.L. & 37 & 25.51 & 3.82 & G. İ. & 18,4 & & \\
\hline & Meslek L. & 30 & 23.66 & 5.74 & & & & \\
\hline & İlkokul & 108 & 25.58 & 4.53 & & & & \\
\hline & Ortaokul & 226 & 25.66 & 3.75 & & & & \\
\hline & B. Sanat M. & 69 & 25.94 & 4.85 & & & & \\
\hline & Toplam & 630 & 25.27 & 4.31 & & & & \\
\hline \multirow[t]{8}{*}{ Ö. İ. olma } & Anadolu L. & 128 & 15.34 & 3.65 & G. A. & 60,28 & 5640 & .000 \\
\hline & Sos./Fen L. & 32 & 16.34 & 3.64 & & & & \\
\hline & İmam H.L. & 37 & 16.86 & 3.25 & G. İ. & 19,69 & & \\
\hline & Meslek L. & 30 & 16.13 & 3.82 & & & & \\
\hline & İlkokul & 108 & 17.17 & 3.07 & & & & \\
\hline & Ortaokul & 226 & 17.23 & 2.94 & & & & \\
\hline & B. Sanat M. & 69 & 17.28 & 3.38 & & & & \\
\hline & Toplam & 630 & 16.72 & 3.34 & & & & \\
\hline
\end{tabular}




\begin{tabular}{lllllllll}
\hline Mesleğe & Anadolu L. & 128 & 8.21 & 1.47 & G. A. & 2,47 & .856 & .527 \\
Bakış & Sos./Fen L. & 32 & 8.21 & 1.64 & & & & \\
& İmam H.L. & 37 & 7.94 & 1.82 & G. İ. & 2,89 & & \\
& Meslek L. & 30 & 8.00 & 1.81 & & & & \\
& İlkokul & 108 & 8.53 & 1.63 & & & \\
& Ortaokul & 226 & 8.34 & 1.77 & & & \\
& B. Sanat M. & 69 & 8.31 & 1.83 & & & \\
& Toplam & 630 & 8.30 & 1.69 & & & \\
\hline
\end{tabular}

Öğretmenlerin yansıtıcı düşünme eğilim puanlarının çalışılan okul türüne göre farklılaşıp farklılaşmadığına ilişkin tek yönlü varvans analizi yapılmıştır. Analiz sonuçlarına göre sürekli ve amaçlı düşünme ( $\mathrm{F}=2,282$; $\mathrm{p}<.05)$, açık fikirlilik ( $\mathrm{F}=2.357 ; \mathrm{p}<.05)$, öğretim sorumluluğu ve bilimsellik $(\mathrm{F}=2.384 ; \mathrm{p}<.05)$, araştırmacı $(\mathrm{F}=2,451 ; \mathrm{p}<.05)$, öngörülü ve içten olma $(\mathrm{F}=5.640 ; \mathrm{p}<.05)$, alt boyutlarında anlamlı bir farklılık bulunmuştur. Sorgulayıcı ve etkili öğretim ve mesleğe bakış alt boyutlarında anlamlı bir farklılık görülmemiştir.

Farklılı̆̆ın kaynağını ortaya koymak üzere Tukey analizi yapılmıştır. Sürekli ve amaçlı düşünme boyutunda Anadolu Lisesi (Ort.29,27; SS: 4,37) ile Mesleki Teknik Eğitim Lisesi'nde (Ort. 27,20; SS: 5,84) görev yapan öğretmenler arasında Anadolu Lisesi'nde görev yapan öğretmenler lehine anlamlı bir farklılık vardır. Anlamlı farklılığın bulunduğu ikinci boyut ise açık fikirlilik boyutudur. Farklılık İmam Hatip Lisesi'nde görev yapan öğretmenler (Ort.24,56; SS: 5,94) ile Anadolu Lisesi'nde görev yapan öğretmenler (Ort. 26,71; SS: 4,47) arasında Anadolu Lisesi'nde görev yapan öğretmenler lehinedir. Yine aynı boyutta Anadolu Lisesi öğretmenleri (Ort.24,71; SS: 4,47) ile Mesleki Teknik Eğitim lisesinde görev yapan öğretmenler (Ort.24,56; SS: 5,94) arasında Anadolu Lisesi'nde görev yapanlar lehine anlamlı bir farklılık vardır. Tukey analizi sonuçlarına göre İlkokul (Ort.27,27; SS: 3,61) ile Mesleki Teknik Eğitim lisesinde görev yapanlar (Ort.24,56; SS: 5,94) ve İmam Hatip Lisesi'nde görev yapanlar (Ort.24,86; SS: 5,28) arasında ilkokul öğretmenleri lehine anlamlı bir farklılık vardır. Öğretim sorumluluğu ve bilimsellik alt boyutunda farklılığın kaynağı İlkokul (Ort.22,53; SS: 3,55) ve Anadolu lisesinde görev yapanlar (Ort.21,45; SS: 4,00) ile aynı şekilde ilkokul ve Mesleki Teknik eğitim liselerinde görev yapanlar (Ort.20,63; SS: 4,67) arasında ilkokulda çalışan öğretmenler lehine bulunmuştur. Araştırmacı alt boyutunda ise farklılığın kaynağı İlkokulda (Ort.25,58; SS: 4,53) görev yapan öğretmenler ile Anadolu lisesinde (Ort.24,32; SS: 4,27) ve Meslek lisesinde görev yapan öğretmenler 
(Ort.24,32; SS: 4,27) arasında yine ilkokul öğretmenlerinin lehine bir farklılık bulunmuştur. Farklılı̆̆ın başka bir kaynağı da Bilim ve Sanat Merkezinde (BSM) (Ort.25,94; SS: 4,85) görev yapan öğretmenler ile Anadolu (Ort.24,32; SS: 4,27) ve Meslek lisesinde görev yapan öğretmenler (Ort.24,32; SS: 4,27) arasındadır. Her iki karşılaştırmada da BSM'de görev yapan öğretmenler lehine anlamlı bir farklılık görülmektedir. Ortaokulda görev yapan öğretmenler (Ort.25,66; SS: 3,75) ile Anadolu (Ort.24,32; SS: 4,27) ve Meslek lisesinde görev yapan öğretmenler (Ort.24,32; SS: 4,27) arasında yine ortaokulda görev yapan öğretmenler lehine bir farklılık bulunmuştur. Farklığın görüldüğ̈̈ son boyut ise öngörülü ve içten olma boyutudur. Anadolu Lisesi ile ilkokul (Ort.17,17; SS: 3,07), ortaokul (Ort.17,23; SS: 2,94) ve BSM'de (Ort.17,28; SS: 3,38) görev yapan öğretmenler arasında Anadolu lisesinde görev yapanlar aleyhine anlamlı bir farklılık vardır. Başka bir ifade ile ilkokul, ortaokul, BSM'de görev yapanların puan ortalamaları Anadolu Lisesinde görev yapmalarındakinden daha yüksektir. Aynı şekilde Meslek lisesinde görev yapan öğretmenlerin ortalama puanları (Ort.16,13; SS: 3,82), ilkokul (Ort.17,17; SS: 3,07), ortaokul (Ort.17,23; SS: 2,94) ve BSM'de görev yapan öğretmenlerin (Ort.17,28; SS: 3,38 ) puanlarından daha düşüktür.

Öğretmenlerin yansıtıcı düşünme eğilimlerinin mesleki kıdem değişkenine göre değişiklik gösterip göstermediğine yönelik yapılan Tek yönlü varyans analizi sonuçları Tablo 6'da sunulmuştur.

Tablo 6. Yansıtıcı düşünme alt ölçek puanlarının mesleki kıdem değişkenine göre Tek yönlï varyans analizi (ANOVA) sonuçlam

\begin{tabular}{|c|c|c|c|c|c|c|c|c|}
\hline Alt Ölçekler & & $\mathbf{N}$ & $\mathrm{X}$ & ss. & & K.O. & $\mathbf{F}$ & $\mathrm{p}$ \\
\hline S. A. & 1-5 Yil & 46 & 30.06 & 3.36 & G. A. & 31,7 & 1.548 & .187 \\
\hline \multirow[t]{5}{*}{ Düşünme } & $6-10 Y_{11}$ & 88 & 28.74 & 4.23 & G.İ. & 20,48 & & \\
\hline & $11-15 Y_{11}$ & 181 & 29.35 & 4.17 & & & & \\
\hline & $16-20 Y_{11}$ & 184 & 28.64 & 5.03 & & & & \\
\hline & 21 ve Üzeri $Y_{1} l$ & 131 & 28.57 & 4.79 & & & & \\
\hline & Toplam & 630 & 28.95 & 4.53 & & & & \\
\hline \multirow[t]{6}{*}{ Açık fikirlilik } & $1-5 Y_{1}$ & 46 & 27.78 & 3.13 & G. A. & 37,49 & 1.780 & .131 \\
\hline & 6-10 Yil & 88 & 26.17 & 4.82 & G.İ. & 21,06 & & \\
\hline & $11-15 Y_{11}$ & 181 & 26.57 & 4.43 & & & & \\
\hline & $16-20 Y_{11}$ & 184 & 25.87 & 4.97 & & & & \\
\hline & 21 ve Üzeri $Y_{1} l$ & 131 & 26.23 & 4.50 & & & & \\
\hline & Toplam & 630 & 26.33 & 5.60 & & & & \\
\hline S. E. & $1-5 Y_{1}$ & 46 & 23.26 & 2.27 & G. A. & 30,35 & 2.061 & .084 \\
\hline \multirow[t]{5}{*}{ Öğretim } & 6-10 Y1l & 88 & 21.84 & 3.72 & G.İ. & 14,72 & & \\
\hline & $11-15 Y_{11}$ & 181 & 21.70 & 3.63 & & & & \\
\hline & $16-20 \mathrm{Y}_{11}$ & 184 & 21.47 & 4.12 & & & & \\
\hline & 21 ve Üzeri Yil & 131 & 21.68 & 4.20 & & & & \\
\hline & Toplam & 630 & 21.76 & 3.85 & & & & \\
\hline
\end{tabular}




\begin{tabular}{|c|c|c|c|c|c|c|c|c|}
\hline Ö.S.ve & 1-5 Yll & 46 & 22.33 & 2.51 & G. A. & 24,67 & 1.995 & .094 \\
\hline \multirow[t]{5}{*}{ Bilimsellik } & 6-10 Yil & 88 & 20.81 & 3.85 & G.İ. & 12,36 & & \\
\hline & 11-15 Y1l & 181 & 21.16 & 3.22 & & & & \\
\hline & $16-20 Y_{1 l}$ & 184 & 20.80 & 3.75 & & & & \\
\hline & 21 ve Üzeri Yll & 131 & 21.29 & 3.62 & & & & \\
\hline & Toplam & 630 & 21.12 & 3.53 & & & & \\
\hline \multirow[t]{6}{*}{ Araştırmacı } & 1-5 Yil & 46 & 26.76 & 2.86 & G. A. & 38,69 & 2.088 & .081 \\
\hline & 6-10 Yil & 88 & 25.16 & 4.68 & G.İ. & 18,53 & & \\
\hline & $11-15 Y_{11}$ & 181 & 25.41 & 3.90 & & & & \\
\hline & $16-20 Y_{11}$ & 184 & 24.77 & 4.57 & & & & \\
\hline & 21 ve Üzeri $Y_{1} l$ & 131 & 25.36 & 4.60 & & & & \\
\hline & Toplam & 630 & 25.28 & 4.32 & & & & \\
\hline \multirow[t]{6}{*}{ Ö. İ. Olma } & $1-5 Y_{1 l}$ & 46 & 18.24 & 1.89 & G. A. & 31,47 & 2.853 & $.023^{*}$ \\
\hline & 6-10 Yil & 88 & 16.69 & 3.40 & G.ì. & 11,03 & & \\
\hline & $11-15 Y_{11}$ & 181 & 16.55 & 3.18 & & & & \\
\hline & $16-20 \mathrm{Y}_{11}$ & 184 & 16.45 & 3.52 & & & & \\
\hline & 21 ve Üzeri Yll & 131 & 16.83 & 3.55 & & & & \\
\hline & Toplam & 630 & 16.72 & 3.34 & & & & \\
\hline Mesleğe & $1-5 Y_{1 l}$ & 46 & 8.67 & 1.55 & G. A. & 2,46 & .853 & .492 \\
\hline \multirow[t]{5}{*}{ Bakış } & 6-10 Yil & 88 & 8.23 & 1.74 & G.İ. & 2,89 & & \\
\hline & $11-15 Y_{11}$ & 181 & 8.32 & 1.70 & & & & \\
\hline & $16-20 \mathrm{Y}_{1}$ & 184 & 8.18 & 1.65 & & & & \\
\hline & 21 ve Üzeri $Y_{1} l$ & 131 & 8.36 & 1.78 & & & & \\
\hline & Toplam & 630 & 8.30 & 1.70 & & & & \\
\hline
\end{tabular}

Öğretmenlerin yansıtıcı düşünme eğilimlerinin mesleki kıdem değişkenine göre değişiklik gösterip göstermediğine yönelik yapılan Tek yönlü varyans analizi sonuçları göre sadece Öngörülü ve içten olma boyutunda anlamlı bir fark bulunmuştur ( $\mathrm{F}=2,853 ; \mathrm{p}<.05)$. Farklılığın kaynağı konusunda yapılan Tukey analizi sonucunda 1-5 yıl kıdeme sahip öğretmenler (Ort.18,24; SS: 1,89) ile 11-15 yıl (Ort.16,55; SS: 3,18) ve 16-20 yıl (Ort.16,45; SS: 3,52) kıdeme sahip öğretmenler arasında 1-5 yıl kıdeme sahip öğretmenler lehine anlamlı bir fark bulunmuştur.

Bağımsız değişkenlerin hangisinin ya da hangilerinin öğretmenlerin yansıtıcı düşünme eğilimleri üzerinde daha çok etkili olduğuna dair yap1lan karar ağacı analizi şekil 1'de verilmiştir.

Karar ağacı modeline göre öğretmenlerin yansıtıcı düşünme eğilimleri üzerinde en çok farklılığa sebep olan bağımsız değişken, görev yapılan okul türü değişkenidir. Buna göre lise türündeki okullarda görev yapan öğretmenler (Ort. 145,18) ile lise öncesi eğitim veren okullarda görev yapan öğretmenlerin (Ort. 150.30) yansıtıcı düşünme eğilim puanları anlamlı şekilde farklılaşmaktadır. Görev yapılan okul türü değişkeni üzerinde ise mesleki kıdem en çok farklılığa sebep olan bağımsız değişkendir. Buna göre 16-20 yıl mesleki kıdeme sahip öğretmenlerin yansitıcı dü- 
şünme eğilim puanları (Ort. 146,07) diğer kıdem gruplarının ortalamalarına (Ort. 152, 19) göre daha düşüktür. 16-20 yıl kıdem üzerindeki değişime en çok etki eden bağımsız değişken branş iken diğer kıdem gruplarına en çok etki eden bağımsız değişken cinsiyet değişkenidir.

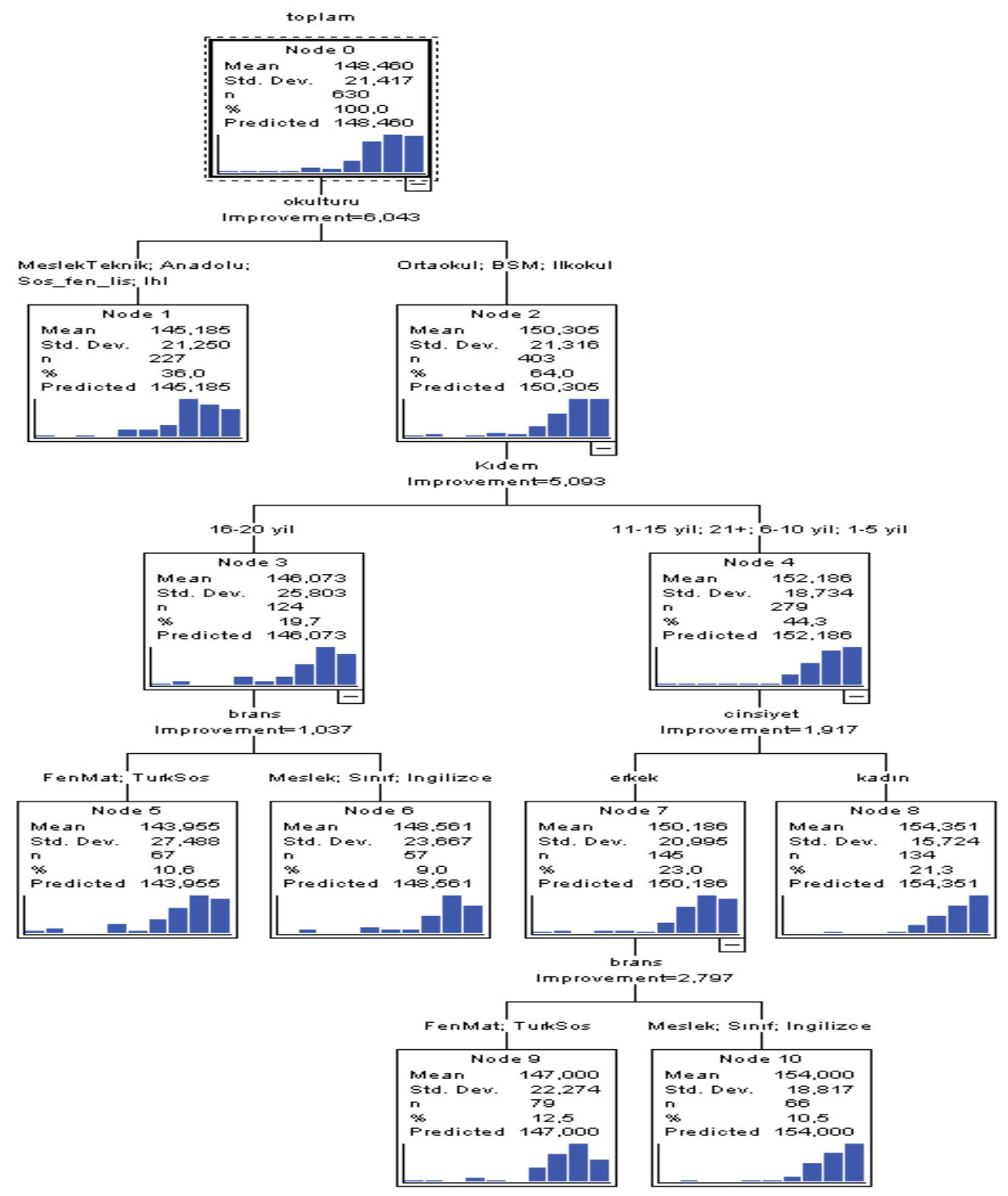

Şekil 1. Öğretmenlerin yansıtıcı düşünme eğilimleri puanlarına ilişkin karar ăgacı modeli. 
Branş değişkenine göre Fen Bilgisi, Matematik, Türkçe, Sosyal Bilgiler branşında görev yapan öğretmenlerin puanları (Ort. 143,96), Meslek Bilgisi, Sınıf ve İngilizce branşında görev yapan öğretmenlerin puanlarından $($ Ort.148,56) düşüktür. Cinsiyet değişkenine göre erkek öğretmenlerin puanları (Ort. 150,186) kadın öğretmenlere (Ort. 154,35) daha düşüktür. Erkek öğretmenlerin puanları üzerinde en etkili değişken yine branştır. Buna göre Fen Bilgisi, Matematik, Türkçe, Sosyal Bilgiler branşında görev yapan erkek öğretmenlerin puanları (Ort. 147,00) Meslek Bilgisi, Sınıf ve İngilizce branşında görev yapan erkek öğretmenlere (Ort. 154,00) göre daha düşüktür.

Öğretmenlerin öğrenim düzeyleri değişkeni diğer bağımsız değişkenlere göre daha az etkili değişkendir, bu sebeple karar ağacı modelinde yer almamiştır.

\section{Sonuç ve Tartışma}

Bu çalışmada, öğretmenlerin yansıtıcı düşünme düzeylerini belirlemek, öğretmenlerin branş cinsiyet, öğrenim düzeyi, okul türü ve mesleki k1demlerine göre bu düzeylerin anlamlı bir farklılık gösterip göstermediğini incelemek amaçlanmıştır.

Öğretmenlerin en yüksek ortalamaları açık fikirlilik alt boyutunda yer alırken, en düşük ortalama mesleğe bakış boyutundadır. Öğretmenler farklı düşüncelere değer verme, yaratıcılık gibi özellikleri taşımakta veya bu fikirlere önem vermektedir. Diğer taraftan öğretmenlerin mesleğe bakış boyut puan ortalamalarının düşük olması öğretmelerin mesleklerine karşı olan tutumlarının düşük olduğunu göstermektedir.

Araştırmada öğretmenlerinin branşlarına göre yansitıcı düşünme düzeyleri arasında anlamlı bir fark var olduğu bulgusuna ulaşılmış olup bu farklılık sadece açık fikirlilik alt boyutunda sınıf öğretmenleri lehinedir. Sınıf öğretmenlerinin yansıtıcı düşünme puanlarının daha yüksek olması, ilköğretim programının daha çok becerilerin geliştirilmesi üzerine kurulu olmasından kaynaklanabilir. Diğer yandan lise öğretim programlarında vurgu daha çok içeriğin öğrenciye kazandırılması üzerinedir. Ayrıca merkezi sınavların varlığı ve bu sınavlarda sorulan soruların daha çok içeriğin ne düzeyde kazanıldığını ölçmeye yönelik oluşu, alan öğretimi yapan öğretmenlerin kendilerini sadece içeriği aktaran bireyler olarak görmesi ile 
sonuçlanabilir. Ayrıca sınıf öğretmenlerinin öğretim uygulamaları bağlamında her türlü soru, tepki ve önerilere daha fazla açık olmaları ve eğitsel etkinliklere daha fazla önem vermeleri de bu duruma yol açmış olabilir.

$\mathrm{Bu}$ araştırmada öğretmenlerinin cinsiyetlerine göre yansıtıcı düşünme düzeyleri arasında anlamlı bir fark var olduğu bulgusuna ulaşılmıştır. Araştırmanın bu bulgusu benzer araştırma bulgularıyla örtüşmektedir (Kaf Hasırcı ve Sadık, 2011). Bayan öğretmenlerin mesleki açıdan kendilerine olan güvenlerinin daha fazla olması, öğretmenlik mesleğinde kendilerini daha yeterli olarak görmeleri (Akbaş ve Çelikkaleli, 2006) bu duruma yol açtığı düşünülmektedir. Aynı zamanda empati kurma, başkalarını anlama, başkalarına öğretme motivasyonlarının yüksek olması, öğrenci görüşlerine daha fazla değer vermesi, eleştirel düşünmesi bu durumun sonucu olarak düşünülmektedir. Ayrıca Dilekli (2015) öğretmenlerin öğretim stilleri üzeri yaptığı araştırmada kadın öğretmenlerin daha demokratik bir sınıf atmosferi oluşturduğu sonucuna ulaşmıştır. Demokratik sınıf ortamı oluşturan öğretmenlerin eleştiriye, öğrenmeye ve işbirliğine daha eğilimi olduğunu da belirtmektedir. Bu noktadan hareketle demokratik sınıf ortamını oluşturan bireyler ile yansıtıcı düşünen bireylerin ortak noktaları olduğu da söylenebilir. Diğer taraftan öğretmenlerin cinsiyetlerine göre yansıtıcı düşünme düzeyleri arasında anlamlı farklılık olmadı ̆̆ına ilişkin araştırma bulguları yer almaktadır (Aslan, 2009; DoğanDolapçıŏlu, 2007; Durdukoca ve Demir, 2012; İnönü, 2006; Kuzu, 2011).

Araştırmada öğretmenlerinin öğrenim düzeylerine göre yansitıcı düşünme düzeyleri arasında anlamlı bir fark olduğu bu farklılığın ise "sürekli ve amaçlı düşünme" alt boyutunda ön lisans mezunları lehinedir. Ön lisans mezunlarının mesleki kıdemleri daha yüksektir. Fakat mesleki k1dem değişkinin analizi sonucunda bu bulguyu destekleyecek bir sonuca ulaşılamamıştır. Bu sebeple ön lisans mezunlarının yansıtıcı düşünme puanlarının daha yüksek olmasının bireysel faktörlerden kaynaklandığı düşünülmektedir.

$\mathrm{Bu}$ araştırmada öğretmenlerin görev yaptıkları okul türüne göre yansıtıcı düşünme düzeyleri arasında anlamlı bir fark var olduğu bulgusuna ulaşılmıştır. İlkokul, ortaokul, BSM'de görev yapanların puan ortalamaları Anadolu Lisesinde görev yapanlardan daha yüksek olduğu, meslek lisesinde görev yapan öğretmenlerin ortalama puanlarının ise ilkokul, ortaokul ve BSM'de görev yapan öğretmenlerin puanlarından daha düşük 
olduğu tespit edilmiştir. Buradan hareketle, bu tür okullarda görev yapan öğretmenlerin öğrencilerin bireysel ilerlemesini daha fazla takip etmesi ve öğrencilerle daha fazla etkili iletişim kurmasının onlarda yansıtıcı düşünme becerilerinin gelişmesine katkı sağladığı düşünülmektedir. Lise eğitimi sonunda ortak bir merkezi sınavın olması ve bu sınavda öğrencilerin lise programındaki içerikten sorumlu olmaları öğretmenleri içeriğin aktarımına odaklamış ve bunun sonucunda öğretim etkinliklerinde ve mesleğe bakış açılarında daimici ve esasici bir felsefeyi temele almalarına sebep olmuş olabilir. Fakat Kaf Hasırcı ve Sadık (2011) ise öğretmenlerin görev yaptıkları okul türüne göre yansıtıcı düşünme düzeyleri arasında anlamlı bir fark olmadığı bulgusuna ulaşmıştır.

Son olarak, bu araştırmada öğretmenlerin mesleki kıdemlerine göre yansıtıcı düşünme düzeyleri arasında anlamlı bir fark olduğu bu farklılık sadece "öngörülü ve içten olma" boyutunda 1-5 yıl kıdeme sahip öğretmenler lehinedir. Bunun nedeni, öğretmen yetiştirme sürecinde lisans düzeyine verilen eğitimlerin yapılandırmacılık felsefesine uygun ve yeni yaklaşımların benimsenmesini sağlayacak şekilde olmasına bağlanabilir. Buna karşılık öğretmenlerin mesleki kıdemlerine göre yansitıcı düşünme düzeyleri arasında anlamlı farklılık olmadığına ilişkin araştırma bulguları yer almaktadır (Dolapçığlu, 2007; Aslan, 2009; Demiralp, 2010; Durdukoca ve Demir, 2012; Hasırcı ve Sadık, 2011; Kuzu, 2011).

Aynı şeklide, karar ağacı incelendiğinde, öğretmenlerin yansıtıcı düşünme eğilim puanları üzerinde en etkili faktörler sırasıyla okul türü, okul türü üzerinde mesleki kıdem, mesleki kıdem üzerinde cinsiyet ve cinsiyet üzerinde branş değişkenleri olarak bulunmuştur. Karar ağacı modelinin ortaya koyduğu bu sonuçlar yapılan diğer analizlerle de tutarlı sonuçları taşımaktadır. 


\title{
EXTENDED ABSTRACT
}

\section{Analyzing Teachers' Reflective Thinking in terms of Some Variables}

\author{
Yalçın Dilekli - Şenol Orakcı
}

Aksaray University

Reflective thinking is a cognitive feature that is consciously learned and developed. Therefore, it is important to have such a thought in the school setting (Wilson and Jan, 1993). Reflective thinking, which is an inquiry approach that attaches importance to constructivism in education, involves rebuilding the individual's experiences (Mahnaz, 1997). At the same time, reflective thinking is a kind of thinking that involves understanding a situation or problem and finding a better solution for it (Kizılkaya and Aşkar, 2009). It can be said that reflective thinking is necessary for teachers because it has a key role in achieving educational objectives, searching for solutions to problems and evaluating their current situation. It is defined as reflecting the teachers' ideas, attitudes and skills about the subject (Semerci, 2007; Dilekli, 2018).

Learning process for teachers should be oriented towards practice. This process should be based on the experience gained from the practices. Therefore, immediately after experimental learning, reflective thinking process should be started (Harrison, Dymoke and Pell 2006). According to Donald et al. (2006), teaching is a complex activity that requires teachers to think about what they do. Good teachers can be even more effective on their teaching. According to this view, teachers' reflective thinking skills encourage critical approaches to the teaching of teachers and, as a result, brings about better practices with it (Oser, Dick and Paltry, 1992; Artzt and Armor-Thomas, 2001; Mayes, 2001; Swain, 1998). If teachers are unaware of errors in implementation, they will not be aware of the measures required to prevent the repetition of these errors, no matter how experienced they are in their field or in teaching methods. From this point of view, through reflective thinking, teachers can question what they are doing, 
reconstruct them, apply these changes and improve themselves (Bölükbaş, 2004). Therefore, reflective thinking is a skill that helps teachers build a relationship between theory and practice and contributes to their professional development (Güney, 2008).

This study aims to investigate reflective thinking levels of teachers and to examine whether there is a significant difference between teachers' gender, education level, type of school and professional seniority and determine which of teachers' gender, education level, type of school and professional seniority were more effective on the reflective thinking skills scores of the teachers. For these purposes, the following questions were addressed:

1. What are the reflective thinking levels of their teachers?

2. Is there a significant difference between the reflective thinking levels of the teachers according to their branches?

3. Is there a significant difference between the reflective thinking levels of the teachers according to their gender?

4. Is there a significant difference between the reflective thinking levels of the teachers according to their educational level?

5. Is there a meaningful difference between the level of reflective thinking according to the type of school?

6. Is there a meaningful difference between the reflective thinking levels of the teachers according to their professional seniority?

7. Which of the faculty, gender, level of education, type of school and professional seniority is more effective on teachers' reflective thinking skills scores?

This study is a descriptive research study conducted by use of the screening model. The screening model is a model that does aims to define the current state as it is in the past or currently (Karasar, 2011). The sample of this study constitutes a total of 630 teachers working in different branches at different levels in different provinces of Turkey. A personal information form was developed by the researchers to collect the data. In addition, "Reflective Thinking Tendency Scale (YANDE)" developed by Semerci (2007) was used in the study. "The Reflective Thinking Tendency Scale" was designed as a 5-point Likert-type scale and consisted of 35 items (20 positive and 15 negative). In the analysis of the data, "independent group 
t test", "one-way variance analysis (ANOVA)", "Tukey test", one of the post-hoc techniques were used in the direction of the study.

As a result of the study, it was seen that there was a significant difference with regard to the reflective thinking levels of the teachers according to their branches, gender, level of education and the type of school they served. Likewise, when "Decision-Tree" model was examined, the most influential factors on the teachers' reflective thinking tendency scores were found to be type of school, upon it professional seniority, upon it teachers' gender, and upon it teachers' branches respectively. The results of the "Decision-Tree" model show consistent results with other analyzes. The results of the study were discussed with the results of similar studies on teachers' reflective thinking.

\section{Kaynakça}

Akbaş, A., Çelikkaleli, Ö. (2006). Sınıf öğretmeni adaylarının fen öğretimi özyeterlik inançlarının cinsiyet, öğrenim türü ve üniversitelerine göre incelenmesi. Mersin Üniversitesi Ĕ̆itim Fakültesi Dergisi, 2(1), 98-110.

Alp, S. ve Şahin. T, Ç. (2008). Eğitimde yansıtıcı düşüncenin önemi ve yansıtıcı düşünceyi geliştirme, Milli Ĕ̆itim Dergisi, 178, 311-320.

Arztz, A.F. ve Armour-Thomas, E. (2001). Becoming a reflective mathematics teacher: A guide for observations and self-assessment. Mahwah, NJ: Lawrence ErlbaumAssociates.

Aslan, G. (2009). Sımıf öğretmenlerinin yansıtıcı düşünme eğilimleri ile sürekli kaygı düzeyleri arasındaki ilişkinin incelenmesi. Yayınlanmamış Yüksek Lisans Tezi. Yeditepe Üniversitesi Sosyal Bilimler Enstitüsü. İstanbul.

Atay, Y. D. (2003). Öğretmen eğitiminin değişen yüzü (1. Bsm). Ankara: Nobel Dağıtım.

Ayers, W. (2001). To teach: The journey of a teacher (2nd ed.),New York: Teachers College.

Bölükbaş, F. (2004). Yansıtıcı öğretimin ilköğretim ikinci kademe öğrencilerinin türkçe dersine yönelik tutum ve başarıları üzerindeki etkililiği. Yayımlanmamış Doktora Tezi. Dokuz Eylül Üniversitesi Eğitim Bilimleri Enstitüsü, İzmir. 
Danielson, C. (1996). Enhancing professional practice: A framework for teaching. (2nd ed.). Alexandria, VA: ASCD.

Demiralp, D. (2010). İlköğretim birinci kademe programlarının öğrencilerin yansıtıcı düşünmelerini geliştirmeye etkisine yönelik öğretmen görüşleri Elazığ ili örneği. Yayınlanmamış Yüksek Lisans Tezi. Fırat Üniversitesi Soysal Bilimler Enstitüsü, Elazı̆g.

Dewey, J. (1933). How we think: A restatement of the relation of reflective thinking to the educative process. Boston: D. C. Heath.

Dilekli, Y. (2015). Öğretmenlerin düşünmeyi öğretmeye yönelik yaptıkları sınıf içi uygulamalar:Özyeterlik düzeyleri ve öğretim stilleri arasındaki ilişki. Yayınlanmamış Doktora Tezi. Sosyal Bilimler Enstitüsü, Balıkesir Üniversitesi, Balıkesir.

Dilekli, Y. (2018). Üst düzey düşünme becerileri , Öğretim İlke ve Yöntemleri, içinde (319-356), Ankara: Maya.

Doğan-Dolapçığlu, S. (2007). Sinıföğretmenlerinin yansıtıcı düşünme düzeylerinin değerlendirilmesi. Yayınlanmamış Yüksek Lisans Tezi. Mustafa Kemal Üniversitesi Sosyal Bilimler Enstitüsü, Hatay.

Donald, R., Deborah, B., J. ve Kim, K. M. (2006). The act of teaching, New York: McGrawHill.

Durdukoca, Ğ. ve Demir, M. (2012). İlköğretim öğretmenlerin bazı değişkenlere göre yansıtıcı düşünme düzeyleri ve düşüncelerindeki öğretmen niteliklerinin yansıtıcı öğretmen niteliklerine uygunluğu. Mustafa Kemal Üniversitesi Sosyal Bilimler Enstitüsü Dergisi, 20, 357374.

Durdukoca, Ş. F. ve Demir, M. (2012). İlköğretim öğretmenlerin bazı değişkenlere göre yansıtıcı düşünme düzeyleri ve düşüncelerindeki öğretmen niteliklerinin yansitıcı öğretmen niteliklerine uygunluğu. Mustafa Kemal Üniversitesi Sosyal Bilimler Enstitüsü Dergisi, 9(20), 357-374.

Gelter, H. (2003). Why is reflective thinking uncommon. Reflective Practice 4 (3), 337-345.

Güney, K. (2008). Mikro-yansıtıcı öğretim yönteminin öğretmen adaylarının sunu performansı ve yansitıcı düşünmesine etkisi. Yayımlanmamış Doktora Tezi. Fırat Üniversitesi Sosyal Bilimler Enstitüsü, Elazı̆̆. 
Harrison, J., Dymoke, S. ve Pell, T. (2006). Mentoringbeginning teachers in secondaryschools: An analysis of practice. Teaching and Teacher Education, 22, 1055-67.

Hasırcı, Ö.K. ve Sadık, F. (2011). Sınıf öğretmenlerinin yansıtıcı düşünme eğilimlerinin incelenmesi. Çukurova Üniversitesi Sosyal Bilimler Enstitüsü Dergisi, 20(2), 195-210.

Husu, J., Patrikainen, S. ve Toom, A. (2006). Examining student teachers' practicum portfolios to develop reflective competencies in teaching.Paper presented in AERA 2006 Annual Conference in San Francisco.

İnönü, Y. (2006). Tarih öğretmenlerinin yansıtıcı öğretmen özelliklerine sahiplik düzeyi: Van örneği. Yayınlanmamış Yüksek Lisans Tezi. Yüzüncü Yıl Üniversitesi Sosyal Bilimler Enstitüsü, Van.

Kaf, H. Ö. ve Sadik, F. (2011). Sınıf öğretmenlerinin yansitıcı düşünme eğilimlerinin incelenmesi, Çukurova Üniversitesi Sosyal Bilimler Dergisi, 20, 195-210.

Karasar, N. (2011). Bilimsel araştırma yöntemi. (22.Bsm). Ankara: Nobel Akademi.

Kızılkaya, G. ve Aşkar, P. (2009). Problem çözmeye yönelik düşünme becerisi ölçeğinin geliştirilmesi. Ĕ̆itim ve Bilim, 34(154), 82-92.

Kuzu, S. (2011). Fen bilgisi öğretmenlerinin yansıtıcı düşünmeye ilişkin görüşlerinin değerlendirilmesi:Şırnak ili örneğii. Yayınlanmamış Yüksek Lisans Tezi, Dicle Üniversitesi Sosyal Bilimler Enstitüsü, Diyarbakır.

Lee, J. H. (2005). Understanding and assessing preservice teachers' reflective thinking. Teaching and Teacher Education, 21(6), 699-715. https://doi.org/10.1016/j.tate.2005.05.007

Loughran, J. J. (1996). Developing reflective practice: Learning about teaching and learning through modelling. London: Falmer.

Mahnaz, M. (1997). Content and nature of reflective teaching: A case of an experiment middle school science teacher. Clearing House, 70(3), 143-151.

Mayes, C. (2001). A transpersonal model for teacher reflectivity. Journal of Curriculum Studies, 33(4), 477-493.

Oser, F., Dick, A. ve Paltry, J. (1992). Effective and Responsible Teaching. San Francisco, CA: Jossey-Bass. 
Semerci, Ç. (2007). Öğretmen ve öğretmen adayları için yansıtıcı düşünme eğilimi (YANDE) ölçeğinin geliştirilmesi, Kuram ve Uygulamada Ĕ̆itim Bilimleri, 7(3), 1351-1377.

Swain, S.S. (1998). Studying teachers' transformations: Reflections as methodology. The Clearing House, 72(1), 28-34.

Tripp, D. (2003). Action inquiry, action research reports, 04.02 .2018 tarihinde www.fhs.usyd.edu.au/arow/arer/017.html adresinden erişildi.

Willard-Holt, C. ve Bottomley, D. (2000). Reflectivity and effectiveness of preservice teachers in a unique field experience. Action in Teacher Education 21(2), 76-89.

Wilson J., \& Jan W.L. (1993). Thinking for themselves: Developing strategies for reflective learning. Australia: Eleanor Curtain Publishing.

\section{Kaynakça Bilgisi / Citation Information}

Dilekli, Y. ve Orakcı, Ş. (2019). Öğretmenlerin yansıtıcı düşünme becerilerinin çeşitli değişkenlere göre incelenmesi OPUS-Uluslararası Toplum Araştırmaları Dergisi, 11(18), 1517-1539. DOI: 10.26466/opus.550187 